\title{
An anniversary left untold. The 400th anniversary of the publishing of the Frankfurt Memorandum
}

\begin{abstract}
The History of Education, one of the courses offered at teacher education studies at the University of Szczecin, has been taught since the 1960's. It was then when Teacher Education College in Szczecin was set up as a branch of Adam Mickiewicz University, Poznań. In 1973 Teacher Education College was transformed into an independent unit - Pedagogy Academy. The establishment of the University of Szczecin in 1985 marked a new chapter in the process of the development of the history of education as a course offered at pedagogical studies. History of Education Department was set up in 1992 and professor Danuta Koźmian was chair of the department throughout its existence. Scientific and didactic work of professor Danuta Koźmian first at Teacher Education College, through Pedagogy Academy and the University of Szczecin has been crucial for the development of the history of education as a course taught at teacher education studies in Szczecin. In 2008 professor Danuta Koźmian retired and the Council of the Faculty of Humanities at the University of Szczecin established the Chair for the History of Education appointing professor Wiesław Andrukowicz, Ph.D its head.
\end{abstract}

Keywords: the University of Szczecin, the Department and Chair for the History of Education, course: the History of Education at the University of Szczecin

[...] tread not on the altars of the past,

Although you are meant to surpass their creation.

(Adam Asnyk, To youth, 1880)

([...] nie depczcie przeszłości ołtarzy

Choć macie sami doskonalsze wznieść

(Adam Asnyk, Do młodych, 1880))

The $17^{\text {th }}$ century was a time of the settlement of religious conflicts across Europe. A disinterest regarding the theological arguments and religious differences had become apparent. The humankind would focus on the exact sciences providing perpetual and cer- 
tain effects. The sciences, including mathematics, astronomy, physics and chemistry, that not long ago had been considered as pagan, would face increased interest and recognition. The belief in reason increased. A new philosophical movement, i.e. rationalism was established. The significance of science and education increased to a degree, so that the entire period would be regarded as the Renaissance period.

This year marks the big, i.e. the $400^{\text {th }}$ anniversary of employing the term didactics by Wolfgang Ratke in 1613. Within the aforementioned context, one should mention the significant dates related to the anniversary. The year 1638 marks an important event for the development of didactics as a scientific discipline. It was the year of publication of the Didactica magna by Comenius. The year 1806 marked another important event for the development of the pedagogical thought, with the release of the Allgemeine Padagogik aus dem Zweck der Erziehung abgeleitet, by Johan Friedrich Herbart. The most significant date for the establishment of Herbart's didactic theories, was the year 1902, when the work titled The Child and the Curriculum by John Dewey was released. Similarly, the year 1910, when the work titled How we think, by the same author, important among the didactic literature, was released, is of similar significance.

\section{Wolfgang Ratke as an inspirer for didactic thought}

Wolfgang Ratke was born on 18 October 1571 in Wilster, northern Germany. Ratke was of middle class descent. He received education in Hamburg. Later on, he took up theology at the Univeristy of Rostock. He graduate, however, without receiving a formal degree. At the time, his relatively low spokesman skills revealed. The lack of success as a preacher, led him to resign from the spiritual life, and to return to his home in Wilster. Between 1600 and 1603, Ratke would develop his linguistic skill, focusing on Hebrew. The following eight years, Ratke spent in the most intellectually progressive environment, i.e. Amsterdam, Netherlands ${ }^{1}$. Inspired by the views of the English philosopher and lawyer, Sir Francis Bacon (1561-1626) he began reflecting upon the creation of a new system of education. In his works, Bacon would harshly criticise the education in humanities. He would accuse his contemporary education with overly drawing upon ancient sources. In his opinion, the ancient inspiration for approaching science and the human teaches dogmatic and receptive thinking. Bacon, however, demanded the trust in own reason, and the shaping of the skill of independent thinking ${ }^{2}$. Inspired by such views, Ratke would spread his own, innovative theories. The Dutch scientific community was not prepared for such theories and did not take them favourably. The theories met with lack of understanding, doubt, even reluctance. Realising the state of affairs, Ratke decided to return to Germany. The year 1610 marks his idea of conducting a fundamental educational reform, with one of its main aims being the unification of Germany. Ratke exercised attempts of present-

\footnotetext{
${ }^{1}$ BERNADR, H., German Teachers and Educators, Hardfort 1878.

2 RUSSEL, B., A History of Western Philosophy, London 1946.
} 
ing his theories and implementing them practically. In 1612 he presented princes, electors, with the proposal of developing of methodological pointers, in order to change and enable youth to learn classic languages, drawing upon their well-established knowledge of their first language. Ratke highlighted the postulate of introducing natural sciences to schools, and of preparing handbooks dedicated to every element of the curriculum. His theories were then rejected, especially by the clergy who feared the loss of influence within the scope of education. The representatives of the clergy wished to maintain control over education, and perceived Ratke's views as hazardous for the established order.

Therefore, one should complement the historical timetable with an additional date the year 1613. It marked the moment, when Ratke - a linguist and reformer presented the parliament with an expanded text, known as the Frankfurt Memorandum. Primarily, the document expressed the author's belief of inventing an efficient and effective method of teaching (especially regarding foreign languages) ${ }^{3}$.

The discussed author related to teaching as an art. By doing that, Ratke highlighted the exceptional, grand and masterful aspect of teaching. However, despite the Renaissance thought and the present spirit of intellectual progress spanning across Europe, Ratke's views met with no appreciation or acceptance. However, Louis V, the Landgrave of HesseDarmstadtt did not reject the progressive theories presented in Ratke's work. Louis established grounds for their implementation. He ordered their critical evaluation, resulting in an opinion/a review of their actual efficiency. Particularly, as numerous elements within the Frankfurt Memorandum, regarded the issue of spreading ant nationalising education which would serve as an instrument of unifying the nation and allowing the Germans to reclaim their former power.

In consequence, the theory of education, as proposed by Ratke, would serve the purpose of developing and solidifying Protestantism within the German nation. The aforementioned was considered as hazardous by the clergy. Previously, they were the ones who controlled and shaped education.

In 1613 Christoph Helvig (a historian, theologian, linguist and a professor of Hebrew at the University of Giessen) along with Joachim Jung (a philosopher, mathematician, natural scientist and a professor at the University of Helmstedt $)^{4}$, presented the prince with the Brief report on Wolfgang Ratichius'Didactica or art of teaching (Kurzter Bericht Von der DIDACTICA, oder LECHRKUNST Wolfgangii Ratichii). The authors of the opinion (i.e. the report) regarding the applicability of Ratke's views, expressed support to his theories. Using the term didactics (similar to Ratke), they regarded it as an art, and a practical skill. One can clearly see that the didactic theory of the time emphasised on the role of the teacher, master and the educator, as the dominant elements were teaching and the appropriate teaching skills ${ }^{5}$.

\footnotetext{
${ }^{3}$ RATKE, W., Gramatica Uniwersale Per La Didattica, Coten 1620.

${ }^{4}$ STÖTZER, P., Ratichianische Schriften mit einer eileitung, Leipzig 1892, p. 60.

${ }^{5}$ QUICK, R.H., Educational Reformers, New York 1890.
} 
The reviewers of Ratke's thought, showed appreciation for the issue of developing and popularising of the (criticised at the time) classroom-lesson system, simultaneously highlighting the economics of teaching ${ }^{6}$. Elite teaching, employing a master - pupil relation (established in previous periods), was common at the time, however, at the beginning of the $16^{\text {th }}$ it had been considered as outdated and unprofitable.

Opinion regarding the theory of teaching proposed by Ratke, noted the proper division of the process of teaching into first the passing of knowledge by the teacher to the group of students, which in turn would be perpetuated by exercise and repetition. Ratke, in regard to his views on teaching, noted the role of the teacher who was given the essential role concerning working with the student. Therefore, didactics was considered as equal to art (ars didactica) portrayed as the passing of knowledge and the shaping of skills ${ }^{7}$.

Considering the fact, that teaching within the theory of Ratke was indivisibly connected with the concept of education, his precious art was to lead to forming of custom, morality and attitudes adequate to faith. The matter was important as the Hussites movement had been spreading since the $15^{\text {th }}$ century. An indication regarding the need for reform within the Roman Catholic Church was apparent, and in the $16^{\text {th }}$ century Germany (by the hands of Martin Luther, who gave the Germans the vernacular translation of the Bible) and other European countries, the reformatory thought flourished, resulting in entire countries breaking away from the domination of the papacy and the Church. Ratke too formulated his thought in the atmosphere of such profound changes, as he, a hundred years after the start of the reformation movement in Germany, wrote on the need of reading and writing in vernacular language.

Numerous indications included within the Frankfurt Memorandum concerns mainly the issues of education currently regarded as preschool and early school. Ratke expressed a view in which he highlighted the urgency of elementary teaching, drawing upon national standards. According to Ratke, such education should become the foundation of further education, continued at higher levels. Ratke suggested a reduction of verbalism for the sake of the role of illustration ${ }^{8}$. Years after, this theory would be expanded upon by John Amos Comenius in his work Orbis sensualium pictus (1658), where he emphasised on the role of imagery for the precise shaping of concepts, and in result, of teaching, currently regarded as teaching according to the didactic principle of illustration. The essential postulate of the principle is the minimal amount of verbalism within the practice of teaching for the sake of illustration. The concept of inducing (lat. inducito), focused around teaching in the specific-to-general order, from the known, to new and unknown, and using the language of current didactics, from the particular to the abstract 9 .

At the beginning of the $17^{\text {th }}$ century, the theories of human cognition were in statu nascendi. Knowledge regarding perception was neither vast nor precise. However, intuition

\footnotetext{
${ }^{6}$ STÖTZER, P., Ratichianische Schriften..., p. 63-65.

${ }^{7}$ Ibidem, p. 38.

8 Ibidem, p. 42-46.

${ }^{9}$ Ibidem, p. 55-56.
} 
and experience allowed Ratke to formulate a theory which is currently more comprehensive and developed, constituting an important link among the didactic principles. Among them is the principle of accessibility.

Ratke took the effort of demonstrating the increased efficiency within the process of teaching, regarding the structural approach to knowledge ${ }^{10}$. Therefore his additional didactic remark was to teach using knowledge divided into disciplines. He was not an advocate of the fragmentary teaching, popular at the time, and based on the dominance of the master's discipline of choice (simultaneously omitting less known disciplines).

Ratke's theories provided inspiration for those who followed him in speculation regarding teaching and education. Among the followers of this noble thought, one can list John Amos Comenius, John Locke or Johann Heinrich Pestalozzi. The aforementioned authors significantly expanded on Ratke's theories, becoming independent agents of social, educational and didactic initiatives. The traces of Ratke's though can also be found in the theory of educational teaching of Johann Friedrich Herbart, who popularised his educational and didactic views in the $19^{\text {th }}$ century.

\section{The forgotten pioneer of didactics}

In the anniversary year 2013, 400 years after publishing the report confirming the validity of claims contained in the Frankfurt Memorandum, one could pose a question regarding the state of contemporary didactics among other educational disciplines and subdisciplines. Has the work of the pioneer of didactic thought been properly and carefully exploited and expanded on?

Literature speaks little of Ratke. Numerous monographs dedicated to the history of education and didactics contain few remarks on the man, whose profound belief and didactic intuition preceded his times significantly. He did not write on the process of teaching, reducing it to arranging the classroom. Ratke referred to issues, speculated upon by the psychology of cognitive process and the psychology of human development.

Ratke inspired numerous monographs and handbooks for mathematical and natural studies as well as for Greek and Latin. Doing so, he referred to the aforementioned (innovative at the time) works on didactics. He was a pioneer of adjusting the content and methods of teaching to the intellectual development of a child. He had accomplished it long before the formal establishment of the theories of human development phases. Ratke demonstrated, that the intellectual processes should be differentiated using age category. $\mathrm{He}$ opposed memory-based learning, deprived of reflection and understanding. Contemporary psychology of cognitive processes, emphasises on the fact that attitude is the basis of all regulation. Ratke postulated that very fact in his memorandum, emphasising on abolishing coercion in the process of teaching. The author thought, that one should inspire children to be curious about things and phenomena, simultaneously avoiding the use of corporal punishment.

\footnotetext{
10 Ibidem, p. 23.
} 
His views contain the thought referring to the belief that the clarity of concept is shaped by the clarity of statements. The theses contained in the Frankfurt Memorandum however positively reviewed by Helvig and Jung, did not immediately become educational practice. In 1622 Ratke defended his views, as they were criticised and doubted. His followers, i.a. John Amos Comenius had a clear pathway in postulating their beliefs, therefore, they are now known and remembered in the history of educational thought.

On the anniversary of the publishing of the Frankfurt Memorandum, I didn't find a single text dedicated to the precursor of didactic thought and his activity, in Polish scientific literature (both within the scope of the history of education and didactics).

Originally published in "Biuletyn Historii Wychowania”, 2013, vol. 30, pp. 149-153 